\title{
Analyzing Typical Characteristics of Central Zagros Potteries during the Chalcolithic Period
}

\author{
Behzad Balmaki ${ }^{1}$, Kamal Aldin Niknami ${ }^{2 *}$, Mohammad Reza Saeedi Harsini ${ }^{3}$ \\ ${ }^{1}$ Department of Archaeology, Islamic Azad University (Hamedan Branch), Hamedan, Iran \\ ${ }^{2}$ Department of Archaeology, University of Tehran, Tehran, Iran \\ ${ }^{3}$ SAMT, Humanities Research Centre, Tehran, Iran \\ Email: Balmaki@iauh.ac.ir, ”kniknami@ut.ac.ir, mohamadreza-sharsiny@yahoo.com
}

Received June 19 ${ }^{\text {th }}$, 2013; revised July 20 ${ }^{\text {th }}$, 2013; accepted August $1^{\text {st }}$, 2013

\begin{abstract}
Copyright (C) 2013 Behzad Balmaki et al. This is an open access article distributed under the Creative Commons Attribution License, which permits unrestricted use, distribution, and reproduction in any medium, provided the original work is properly cited.
\end{abstract}

\begin{abstract}
Some 152 Chalcolithic sites were identified by the means of an archaeological surface survey in the Central Zagros mountainous region. As a whole, the analysis of data shows that the majority volume of finding pottery groups is classified as Red-Slipped Wares belonging to the Late Chalcolithic period. Beside this, the Black on Buff Wares and also the Impress Dalma Wares (Middle Chalcolithic) are the two types dominating the samples. The altitude of the settlements has risen by transition from the Early to the Late Chalcolithic periods. By Middle Chalcolithic we confronted different kinds of potteries indicating an improvement in the pottery making techniques or communicating with the neighboring regions. The Late Chalcolithic societies have witnessed a decline in the pottery types produced, but dramatic increases in the production rates. All factors show that in the Late Chalcolithic, population has been increased and a category of settlement systems have been propagated in the region which includes agricultural village-based pastoralism and nomadism.
\end{abstract}

Keywords: Iran; Central Zagros; Chalcolithic Period; Pottery Types; Archaeological Survey

\section{Introduction}

The Central Zagros Mountains (CZM) has been considered as a most prominent region in the archeological studies of the Middle East and Iran as part of the so-called Fertile Crescent. Central Zagros, as a bridge connecting the Iranian central plateau to the Mesopotamian lowlands, takes a special place in the Middle Eastern archaeological studies (Braidwood et al., 1983; Braidwood, 1958, 1960a, 1960b; Meldgard et al., 1963; Hole, 1987, 2011; Mortensen, 1972, 1974; Gilbert, 1975; Zagarell, 1975; Smith, 1976, 1990; Smith \& Mortensen, 1980; Henrickson, 1985; Abdi, 2003, Niknami \& Nikzad, 2012).

In this region the concealed hints of culture before the historical eras can be revealed as its natural and geographical characteristics has led to turn out to be the noticeable earliest period of human communities. The advent of various changes in the human-ecology relationships, the growing population, outbreak of cultural exchanges, craft specialization, development of tools technology, further concentration on food productions and productivity of nature and rural life are being regarded as highly significant cultural criteria of this period. Fundamental changes in texture, pottery production technique, mass production and high quality of some pottery types are the most important features of Chalcolithic pottery production strategies. All these changes were a continuing process in the mentioned period and at the end of this period, potters were equiped with sufficient experience of production. Variety of potteries

\footnotetext{
*Corresponding author.
}

belonging to Chalcolithic period can be found in the CZM. This diversity in the Early Chalcolithic (EC) to the Late Chalcolithic (LC) is accompanied with changes in the quality as well as its decorations, that it would be different from place to place. In the regions of the Early, Middle and Late Chalcolithic, the traces of potteries and chipped Stones were studied based on the broad excavations carried out for example in Godin Tepe, Seh Gabi; Shahnabad (Young, 1969, 1974) and Giyan (Contenau \& Ghirshman, 1935) project. But more generally the Mahidasht/Kermanshah studies (Levine \& Mcdonald, 1977; Levine, 1975), Malayer (Howel, 1979), north east of Luristan (Goff, 1971; Mortensen, 1974) and Kangavar valley can be consented as the base for the Chalcolithic recognitions (Young, 1975; Young \& Smith, 1966).

In the search for Chalcolithic pottery in the CZM, the researchers explored fine-made but often painted buff wares such as those have been found before at Halaf and Ubaid of Mesopotamia which were fired at a high temperature furnace. Frank Hole believes that buff ware began in some earliest villages from sixth millennium BC and in some other from fifth millennium BC (Hole, 1987). Thus all pottery types found from Chalcolithic regions are hand-made, chaff tempered and have the combination of a light brown to a red range slip (Henrickson, 1991: p. 278). The purpose of this paper is statistical study of the characteristic pottery assemblages of the CZM Region, in the Early, Middle and Early Late Chalcolithic. By this way and based on preliminary pottery data, in fact we try to determine a settlement pattern in the next studies. 


\section{Geographical Location of the Study Area}

Regarding the administrative divisions of the provinces of Iran Central Zagros includes center of Kermanshah province, some areas of the eastern parts of Hamedan, some northern parts in Kurdistan and northern proportions of Luristan and Ilam provinces (Figures 1 and 2).

Based on geographical maps, a number of researchers consider this region much broader than the Kermanshah, Hamedan, Ilam, Kurdistan and Luristan provinces, but Young believes that this region belongs to the center of Kermanshah province and its surrounding valleys (Young, 1963: p. 16).

This geographical area possess high mountains, vast plains and various valleys (Stocklin, 1968) that was accounted as an individual feature for people who provided their place of living and then left settlements and frequent traces.

The data for this study comes from an archaeological survey carried out in the eastern parts of CZM range such as Asad Abad, Nahavand, Kangavar, Harsin and Sahne. Totally from

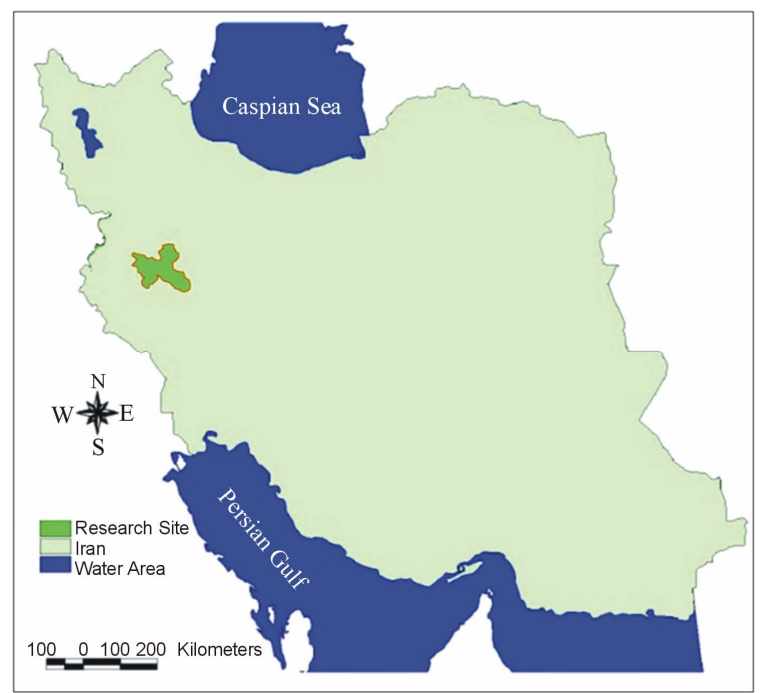

Figure 1.

Map showing location of study area in Iran.

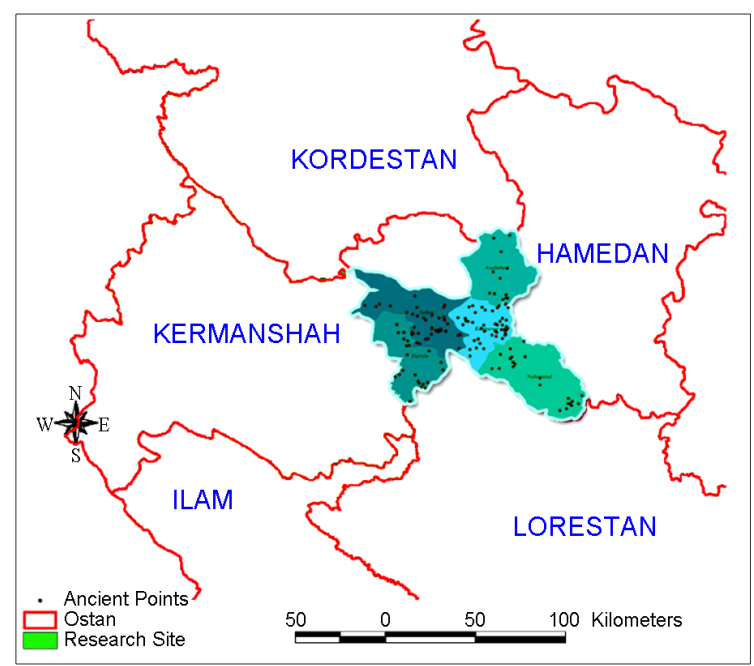

Figure 2.

Map showing location of study area in Iran.
152 archaeological sites sherds were collected and studied (Figures 2 and 3). Potteries were classified into 10 known groups according to the Chalcolithic pottery types of western Iran.

\section{Materials and Methods}

The needed information of this study is obtained through the archaeological survey and sampling. In order to number the sites, the first and second letter of each province is used. According to that (As) stands for Asad Abad, (Nh) for Nahavand, (K) for Kangavar, (S) for Sahne and $(\mathrm{H})$ for Harsin. Totally about 152 sites were identified and random sampling strategy was used to collect surface data.

The abbreviation used for pottery classifications are as follow:

J Ware (JW), Impress Dalma Ware (IDW), Dalma-Painted Ware (DP), Dalma-Ubaid Painted (DUP), Seh-Gabi Painted (SGP), Black on Buff (BOB), Red on Buff (ROB), Red-Slipped Ware (RS), S-Shaped Ware (S), Chipped Stone (CHS).

\section{Classification of Sites Based on the Surface Findings}

The chronology of the sites is concluded based on the survey and classifying of the assemblages as well as the analogy to the previous studies. In many cases, regarding the similarity of the pottery in different sites the possibility of accurate relative chronology is very complicated and requires data coming directly from excavations sherds gathered from the sites were divided into three groups of Early, Middle and Late Chalcolithic as well as an unknown group of Chalcolithic wares which were confronted for the first time. Table 1 shows the number of pottery sherds classified into three Chalcolithic periods and an unknown class of sherds (see also Figure 4).

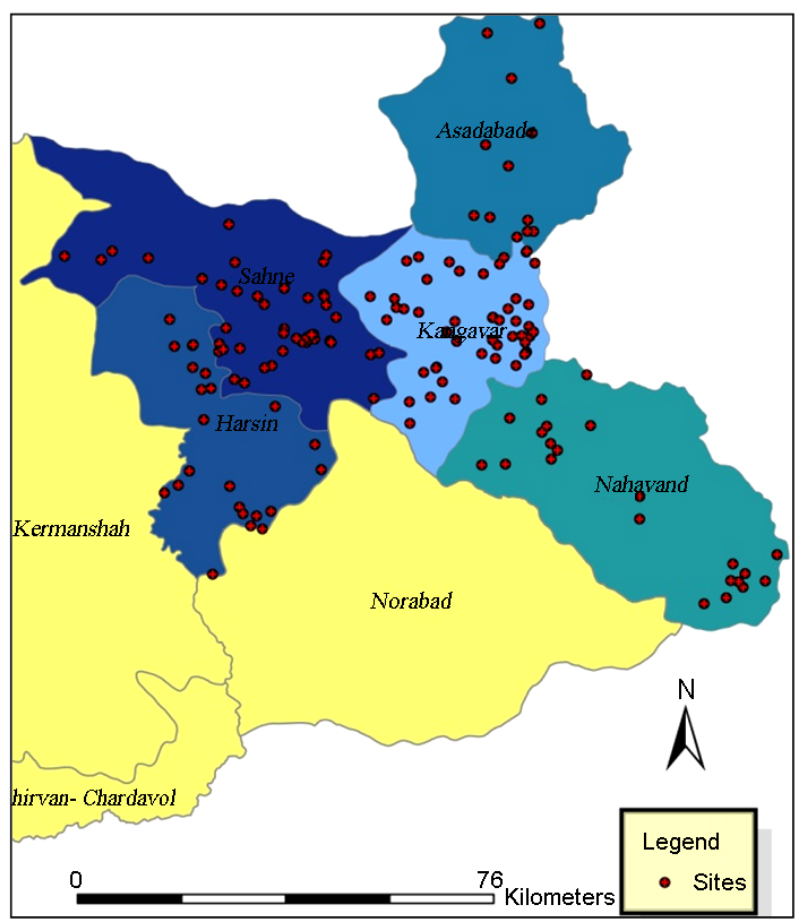

Figure 3.

Distribution of archaeological sites across the study area. 
Table 1.

Number of pottery sherds classified into three Chalcolithic periods and an unknown.

\begin{tabular}{cccc}
\hline Period & Number of sites & Area $\left(\mathbf{m}^{2}\right)$ & Elevation $(\mathbf{m})$ \\
\hline E. C. & 26 & 5235.11 & 1517.26 \\
M. C. & 51 & 10597.45 & 1531.56 \\
L. C. & 110 & 11278.18 & 1549.90 \\
Unknown C. & 21 & 8972.14 & 1453.42 \\
\hline
\end{tabular}

E = Early; $\mathrm{M}=$ Middle; $\mathrm{L}=$ Late; $\mathrm{C}=$ Chalcolithic .

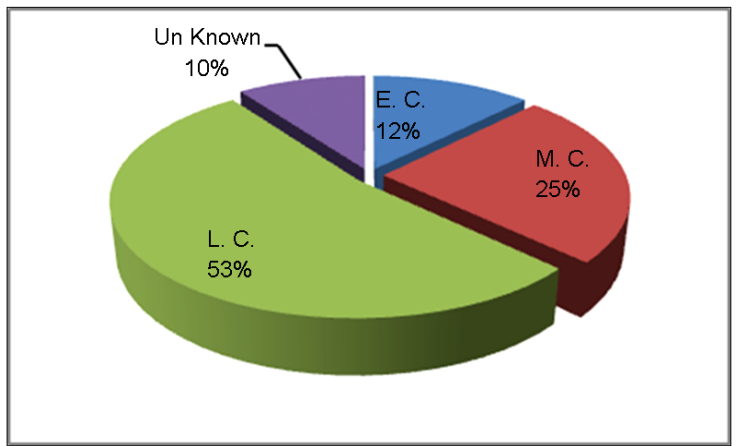

Figure 4.

Percentage of archaeological sites during each Chalcolithic periods.

\section{Classifying Pottery Types According to Chronological Sequence of the Region}

\section{Early Chalcolithic Period, Shahnabad Phase (Godin XI)}

Through the studies conducted in the region the traces of this phase have been observed in Mahidasht and Kangavar of CZM and Nahavand and Malayer valleys. These regions are located toward the old great Khorasan road to the west (Henrickson, 1991: p. 279; Henrickson \& Mcdonalds, 1983: pp. 630-643). Among the potteries of this period found in Seh Gabi Tepe/ Mound C, there have been buff straw-tempered wares known as Shahnabad which are regarded as representative to the potteries of this period (Levine, 1975: pp. 31-44). Some types of Shahnabad wares have been painted by motif of stacked solid traingles on a line in the inner edge. The forms are almost plain and invariant. The radiocarbon samples of Shahnabad phase at Mound C, declare the date of the end of sixth millennium B.C. (Levin \& Young, 1986: p. 17). By our survey no potteries of Shahnabad kind were found, but we have been able to found the well-known wares called as J ware (JW).

This is characterized by a thin and fine body, tan to reddish buff paste, usually red- or black-slipped or both and decorated with various combinations of black, red and white-painted lines or simple geometric motifs. The $\mathrm{J}$ wares may be a derivation of the painted wares of Halaf in Mesopotamia, although they are technically simpler (Henrickson, 1985a: p. 69). Through our investigation $\mathrm{J}$ wares were found at 3 sites which were generally associated with other kinds such as DUP, BOB, ROB and IDW types (Table 2 and Figure 5). From 23 sites of Chalcolithic period we have found Chipped Stone remains were spread on the surfaces.

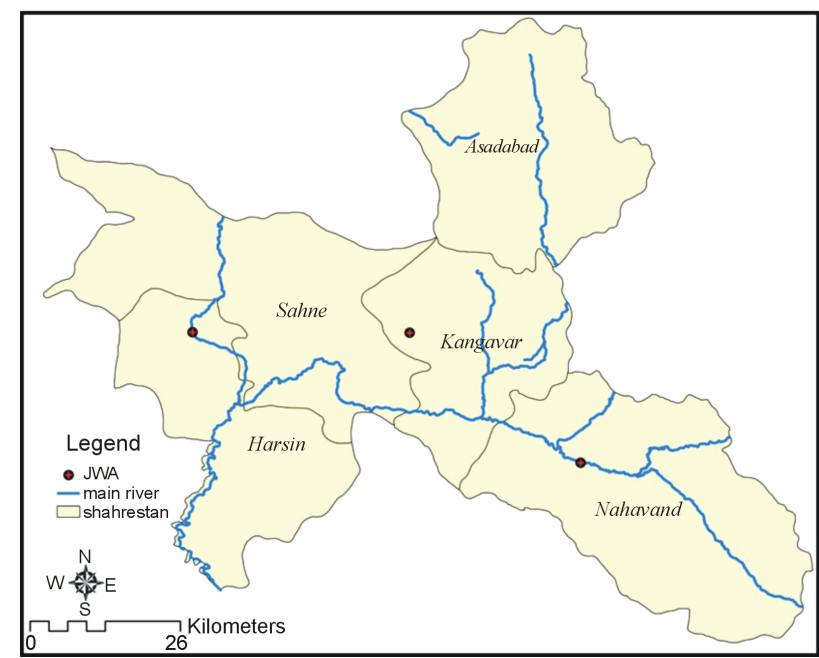

Figure 5.

JW sites location on the map of the study area.

\section{Middle Chalcolithic, Dalma Phase (Godin X)}

Dalma refers to an Early MC site in the south western part of Urmia Lake (Hamlin, 1975: p. 127). It is a name has been given to the pottery styles which were produced in this site. Apart from Dalma itself, this kind of pottery were also found from the sites located in western Iran such as Godin and Seh Gabi. In Seh Gabi the Dalma ware was found in the Mound B and some holes (Young, 1963: pp. 38-39) and they were classified as DPW and IDW. DPW were divided into four sub-classes stylistic groups of Monochrome, Bichrome, Streaky and Dalma-Ubaid.

The Monochrome Dalma wares were not well baked and were generally crude, chaff-tempered and its surface slipped by a cream or dark red slip or covered using gloss matt. The Bichrome Dalma wares are simpler and rarer than the Monochrome samples. These types of samples are found in the first layers of Seh Gabi/Mound B with decoration in red and black on a cream ground. The important point is that no Bichrome was found at Dalma Tepe itself or any of the Azarbayjan sites from this period (Levine \& Young, 1986: p. 21) and this type is specific of Kangavar valley. The type of Dalma streaky is quite different. These wares are often burnished after painting. The mentioned wares are confined to the early levels of Seh Gabi/ Mound B. The Dalma Bichrome wares were found during these surveys from 4 sites. In the sites possessing Dalma Phase other kind of potteries including RS, BOB, ID, DUP and SGP were found (Table 2 and Figure 6).

\section{Dalma-Ubaid Painted Wares}

This kind of pottery was discovered from 4 sites. One site is located in Kangavar valley, two sites in Sahne plains and Harsin and the other in Nahavand plain. There have been findings such as potteries of RS, BOB, IDW, JW, DP and Chipped Stones (Table 2 and Figure 7).

\section{Impressed Dalma Wares}

These wares possess impress drawings and have been decorated with variant methods on the surface. The entire outer surface is manipulated in a wide variety of impressions, excision and the in a very dense and random patterns. In fabric it is similar to the DP, with a surface that has a thick dark red or 
Table 2.

Major pottery types of Chalcolithic period classified for the study area.

\begin{tabular}{|c|c|c|c|c|c|c|c|c|c|c|c|c|c|c|c|c|}
\hline \multirow{2}{*}{ 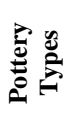 } & \multirow{2}{*}{$\begin{array}{l}\text { Number } \\
\text { of Sites }\end{array}$} & \multicolumn{2}{|c|}{ Attributes } & \multicolumn{3}{|c|}{ Chronology (Site) } & \multicolumn{10}{|c|}{ Other Findings (Site) } \\
\hline & & $\begin{array}{c}\text { Altitude } \\
\text { Average (m) }\end{array}$ & $\begin{array}{c}\text { Area } \\
\text { Average }\left(\mathrm{m}^{2}\right)\end{array}$ & U工工 & U & U્ય & 島 & 3 & ถิ & కั & 3 & ज్ & $\stackrel{0}{0}$ & ○ै & 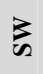 & $\mathscr{q}$ \\
\hline JW & 3 & 1640 & 5699.66 & 3 & 3 & 2 & 0 & 3 & 0 & 1 & 2 & 0 & 0 & 3 & 0 & 2 \\
\hline DP & 4 & 1561.75 & 5636.75 & 2 & 4 & 3 & 1 & 1 & 4 & 0 & 1 & 0 & 0 & 3 & 0 & 2 \\
\hline DUP & 4 & 1525.75 & 17940 & 1 & 4 & 3 & 1 & 0 & 1 & 4 & 1 & 1 & 0 & 3 & 0 & 2 \\
\hline IDW & 29 & 1545.72 & 10488.79 & 10 & 29 & 21 & 7 & 2 & 0 & 1 & 29 & 4 & 4 & 16 & 1 & 21 \\
\hline SGP & 9 & 1512.77 & 8813.77 & 2 & 9 & 7 & 1 & 0 & 1 & 0 & 4 & 9 & 0 & 3 & 1 & 6 \\
\hline ROB & 6 & 1509.5 & 7322.83 & 3 & 6 & 5 & 2 & 1 & 0 & 0 & 4 & 0 & 6 & 4 & 0 & 5 \\
\hline ВОВ & 29 & 1545 & 12684.75 & 8 & 29 & 25 & 5 & 3 & 0 & 3 & 16 & 3 & 4 & 29 & 1 & 24 \\
\hline SW & 5 & 1532 & 17455 & 0 & 1 & 5 & 0 & 0 & 0 & 0 & 1 & 1 & 0 & 1 & 5 & 2 \\
\hline RS & 105 & 1556.6 & 11290.628 & 18 & 40 & 105 & 16 & 2 & 2 & 2 & 21 & 6 & 5 & 24 & 3 & 105 \\
\hline
\end{tabular}

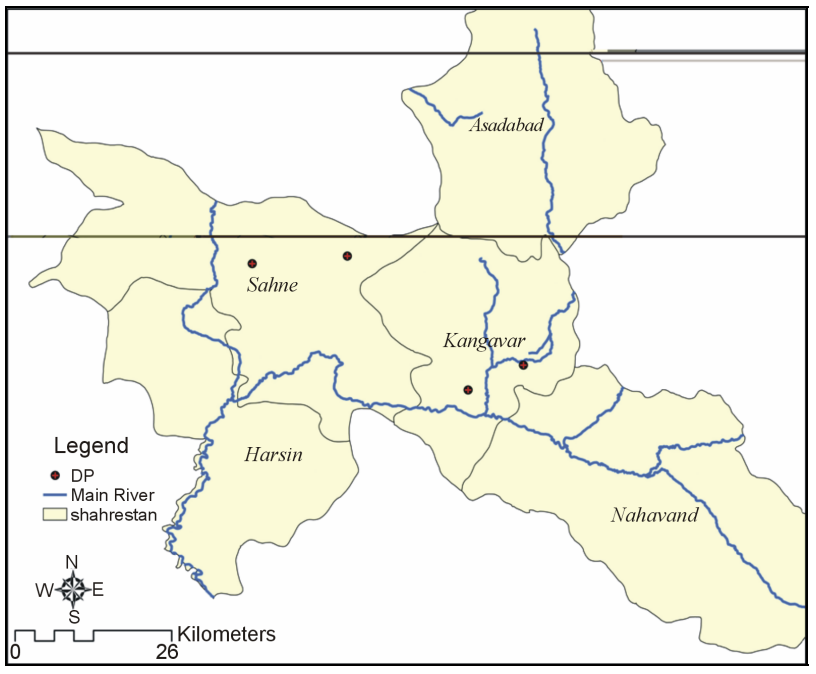

Figure 6.

DP sites location on the map of the study area.

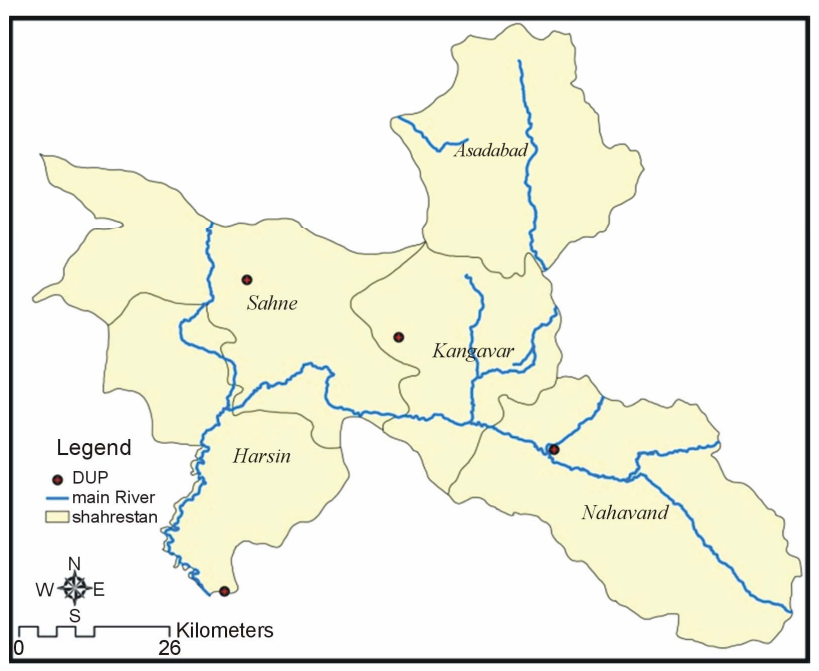

Figure 7.

DUP sites location on the map of the study area. brown slip. All the potteries are hand-made and their most common form is a wide-mouth pot with a short vertical neck and ledge just below the neck (Levine \& Young, 1986: p. 21). In this case, we can refer to other groups of wares. The DUP and the BOB are appeared during a limited period in Dalma collection. Both of these buff wares are fine, thickness and hard (Levine \& Young, 1986: p. 29). In our project, the IDW types have been obtained from 29 sites 10 of which just from Nahavand vicinity (Table 2 and Figure 8).

\section{Middle Chalcolithic/Seh Gabi Period (Godin IX)}

Following upon the Dalma assemblage is the Data from the Seh Gabi assemblage indicates technical progress in pottery production than Dalma wares. The buff wares were finer than before with a distinctive thick, shiny and vitrified black paint. A series of red slipped wares usually burnished and sometimes fingertip impressed are obvious on it like ID wares (Levine \& Young, 1986: p. 29). Potteries for the Godin IX sites in Kangavar valley are similar to those from Nahavand and Malayer (Young, 1966: pp. 228-239; Howel, 1979: pp. 156-157).

\section{Seh Gabi Painted Wares (SGP)}

During the second part of the MC, upper Seh Gabi/Mound B, is characterized by the Seh Gabi Painted (SGP) wares, it is likewise seen to be contemporary with the Pisdeli-wares occupations in Solduz-Ushnu (Henrickson, 1985: p. 70). We observed this kind of pottery in 9 sites of which 4 sites in Kangavar valley, 4 sites in Sahne plain and Harsin and one in Nahavand plain (Table 2 and Figure 9).

\section{Middle Chalcolithic/Godin Period VIII}

The pottery wares of Godin VIII are often smaller and their characteristics are presented to have a fine black on buff similar to the BOB wares which at first were recognized by Levine in the Mahidasht plain. Although this kind of pottery can be viewed as the continuation of Seh Gabi traditions, but in the course of motives and production techniques they are different from each other. The significant point is that, the potteries assigned to this period were not presented in Kangavar and might be collected from the surface of Tepe Giyan (Levine \& Young, 


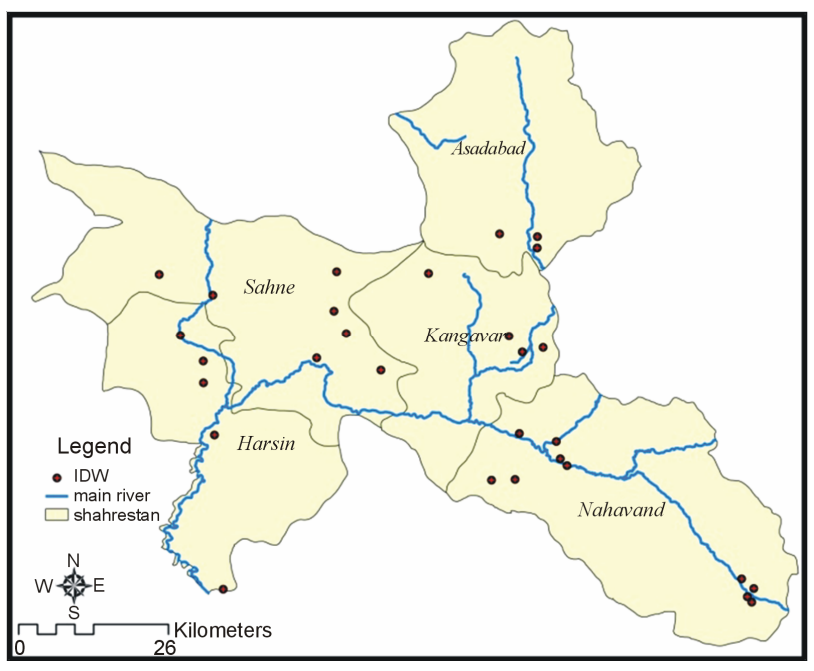

Figure 8.

IDW sites location on the map of the study area.

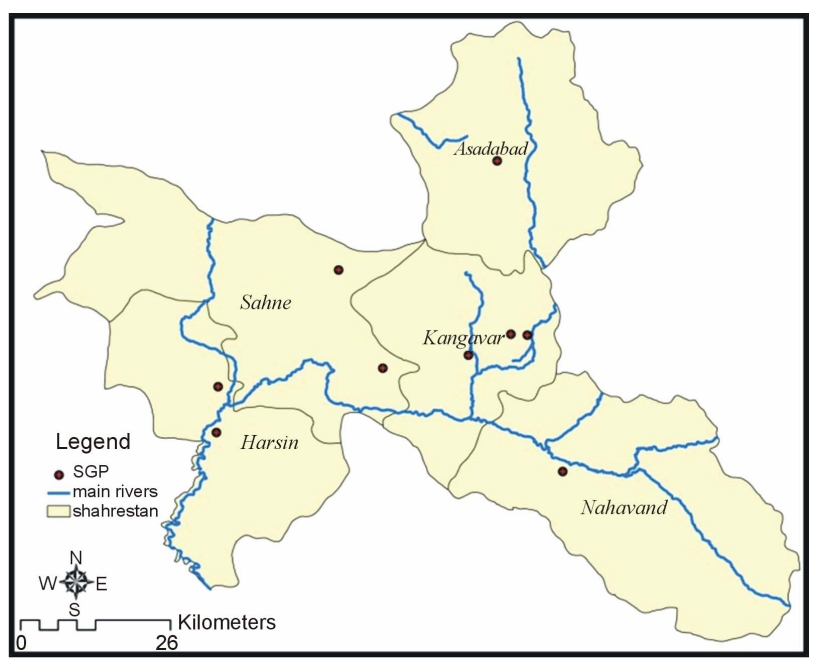

Figure 9.

SGP sites location on the map of the study area.

1986: p. 33). In chronological order Godin VIII is assumed to be the terminal phase of MC before starting the LC phase.

\section{Red on Buff Ware (ROB)}

This thin buff wares which are mostly observed in Nahavand plain, have been represented in 6 sites (Table 2 shows the number of sites producing $\mathrm{ROB}$ and associated findings, see also Figure 10).

\section{Black on Buff Ware (BOB)}

These buff wares discovered from 29 sites of the inter-mountainous plain of Sahne. Sites possessing BOB, associated with other data including IDW, ROB, RS, SGR, JW and DUP (Table 2 and Figure 11).

\section{Early Late Chalcolithic Period}

The Late Chalcolithic is started with Godin VII period. Two of the most significant assemblages of late Chalcolithic are recognized through accurate chronology. These two collections

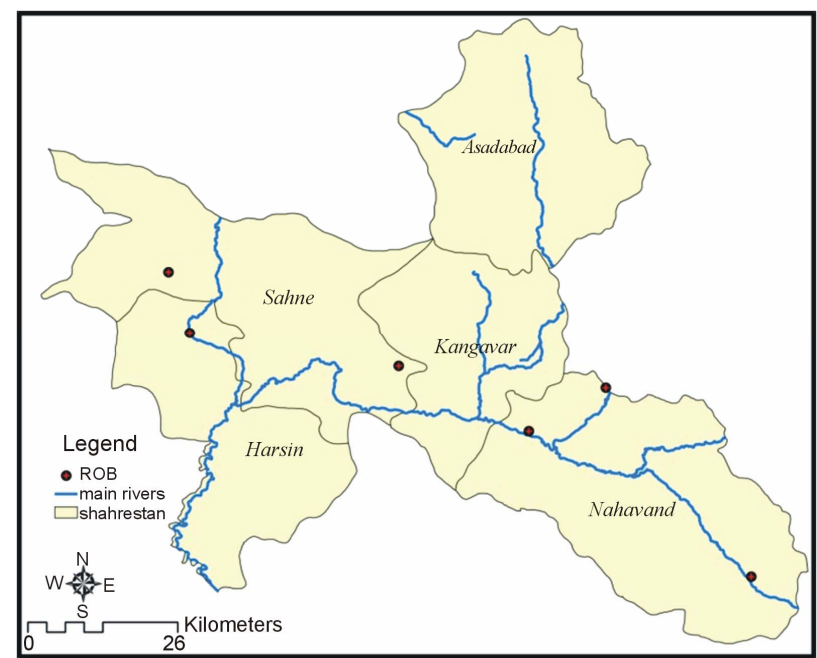

Figure 10.

ROB sites location on the map of the study area.

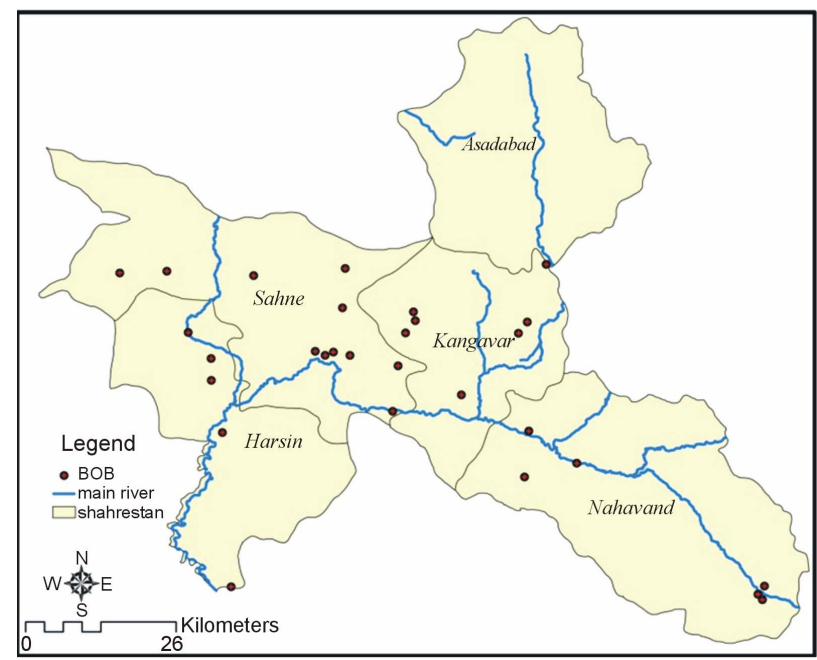

Figure 11.

BOB sites location on the map of the study area.

are known as period VII (Hoseinabad) and period VI (Cheshmehnosh) (Levine \& Young, 1986: p. 33). All the obtained wares of this stage are hand-made and are classified into 4 groups of coarse, semi-coarse, plain and fine wares (Young, 1969: p. 5). Despite an increase in kinds of buff wares the amounts of coarse wares have decreased compared to the previous period. The form of wares includes hemispheric bowls with inverted rim and hemispheric bowls with vertical walls which possess low to average depth. Pots and jars have appeared during this period.

Based on an outstanding and special form, the plain buff wares are typical of this period. Red-Slip wares (RS) are propagated as before but with lesser percentage, such as eight to ten percent.

The upper concaved walls are the other typical wares of this period as well as the painted wares which characterize Godin VI from the previous periods. Motives were primitive and simply geometric, in some wares abstracted designs of animals and birds were used as motives (Levine \& Young, 1986: p. 40). Some parts of potteries belonging to Godin VII and VI have 
been also identified in Tepe Giyan (Henrickson, 1985, Table 1). Moreover, a recent classification divided the Early Late Chalcolithic period itself into two levels of Early Godin VI and Middle and Late Godin VI periods (Badler, 2002: pp. 80-109).

\section{S-Shaped Wares}

Pottery Fragments of S-shaped wares were obtained from 5 sites which include 3 sites from Kangavar valley, 1 site from Sahne and 1 site from Nahavand plain. In the sites consisting of $\mathrm{S}$ wares, other data such as the RS, BOB and ID potteries were also presented (Table 2 and Figure 12).

\section{Red-Slipped Wares (RS)}

These wares are chaff-tempered, have a smoothed surface and are made up into vessels which are coarser and thickerwalled than those in the Buff ware groups. The potteries of this group were found from the most sites; Kangavar 47 sites, Sahne 38 sites and Harsin 20 sites. Table 2 indicates the amount of sites producing RS as well as its associated findings (Figure 13).

These wares are chaff-tempered, have a smoothed surface and are made up into vessels which are coarser and thickerwalled than those in the Buff ware groups. The potteries of this group were found from the most sites; Kangavar 47 sites, Sahne 38 sites and Harsin 20 sites. Table 2 indicates the amount of sites producing RS as well as its associated findings (Figure 13).

\section{Discussion and Conclusions}

Analyzing pottery type assemblages collected from the sites of the study area shows that the types of RS, BOB and ID of LC period, dominated the assemblages respectively (see Figure 14 and Table 3). Regarding the location of pottery types located on the different elevations it is shown that sites containing the J Wares of EC period have been located at the highest elevations than the other.

Considering the pottery types location elevations indicate an increasing change in the settlement elevations occurred by transition from EC to LC. This trend is highly recognizable for all other types of the assemblages. The lowest altitude concerning the CHS type which begins from the EC and then is continued with ROB and SGP types at the beginning of Godin XI and VII, and finally ended up with RS wares in Godin VII. In this case the $\mathrm{J}$ Wares are considered as exceptions because of their rare representations on the sites (Figure 15).

\section{The Settlement Pattern and Distribution of Ware Types in the Region}

As has been identified, 57.89 percent of our visited sites are located in the altitude of $1500-1800 \mathrm{~m}$ on the eastern intermountainous face of Zagros The area are drained by several stream branches and because of the steep slopes of regions, there have been a number of seasonal flows drained by the melting ices through the warmer times (Figure 16).

Since the changes of slopes are concaved according to morphology of region, the slope ends up in the neighboring plains from summit. Density of sediments eroded from the mountains and deposited by the seasonal canals created the widespread alluvial plains inland attracting dwellers to occupy throughout the history of the region.

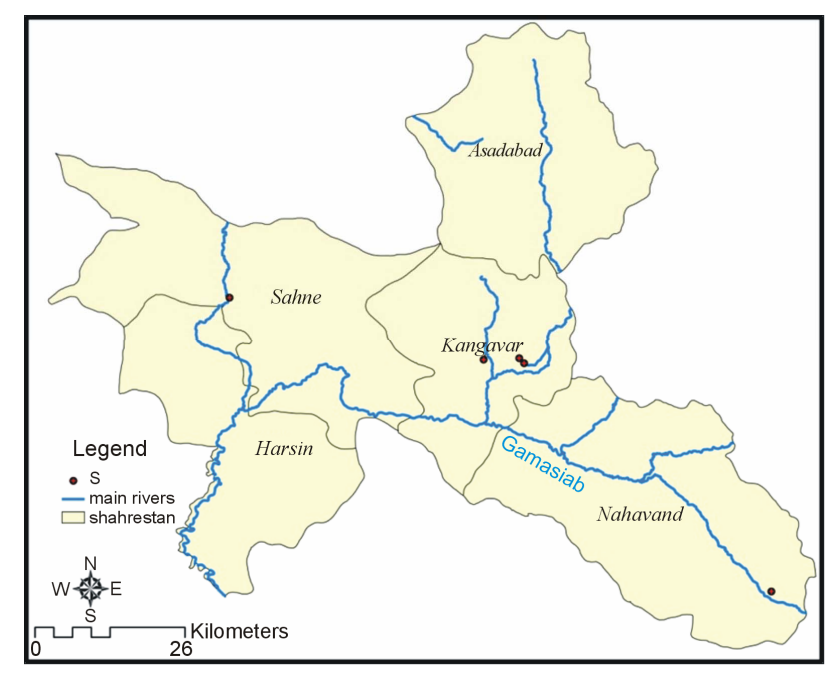

Figure 12.

SW sites location on the map of the study area.

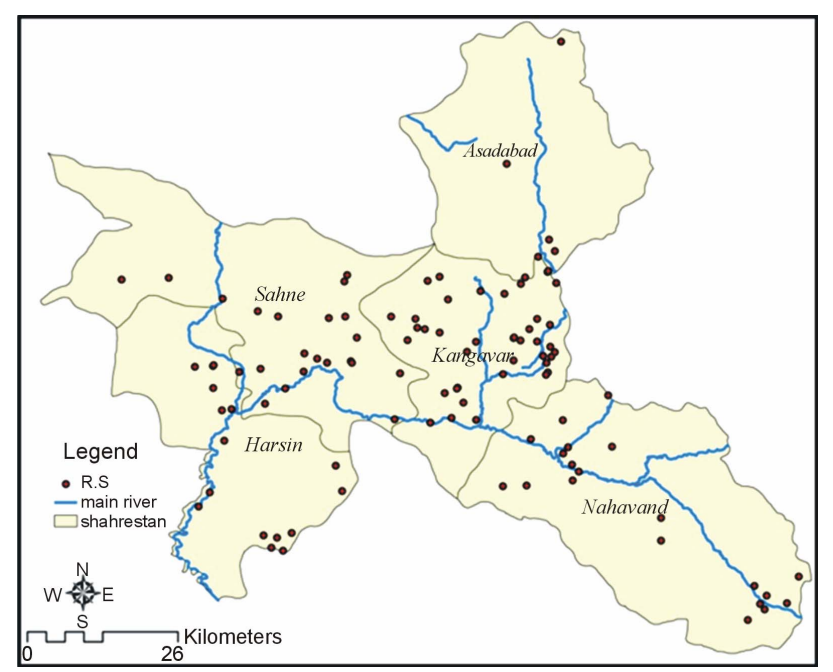

Figure 13.

RS sites location on the map of the study area.

Table 3.

Area covered by each pottery group.

\begin{tabular}{ccc}
\hline Pottery type & Total Area $\left(\mathrm{m}^{2}\right)$ & Percent \\
\hline DP & 71,760 & $3 \%$ \\
S & 87,225 & $4 \%$ \\
SGP & 79,324 & $3 \%$ \\
DUP & 22,545 & $1 \%$ \\
CHS & 150,480 & $6 \%$ \\
JW & 17,099 & $1 \%$ \\
ROB & 43,937 & $2 \%$ \\
IDW & 311,019 & $13 \%$ \\
BOB & 367,858 & $16 \%$ \\
RS & $1,185,516$ & $51 \%$ \\
\hline
\end{tabular}

Moreover, about 62.5 percent of the sites have been located in a distance less than $1000 \mathrm{~m}$ from the rivers and seasonal canals (Table 4). For the settlement patterns of Chalcolithic sites it is evident from Table $\mathbf{4}$ and Figure 16 that distance to 


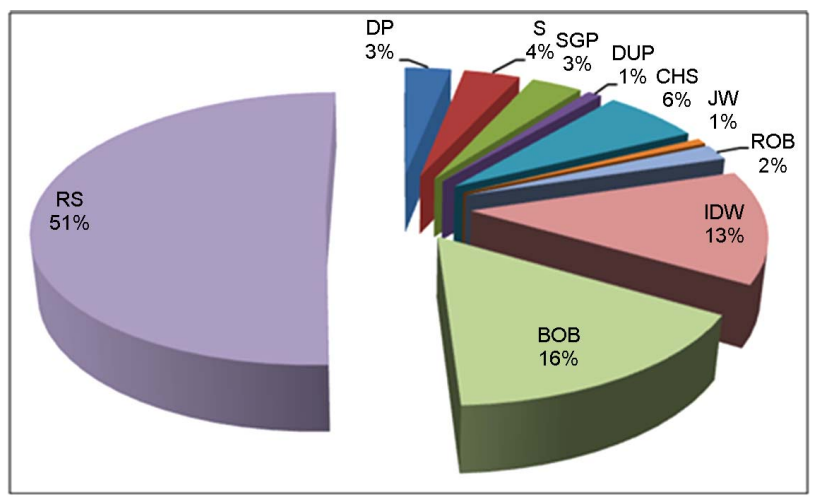

Figure 14.

Percentage of each pottery group identified from the pottery assemblages.

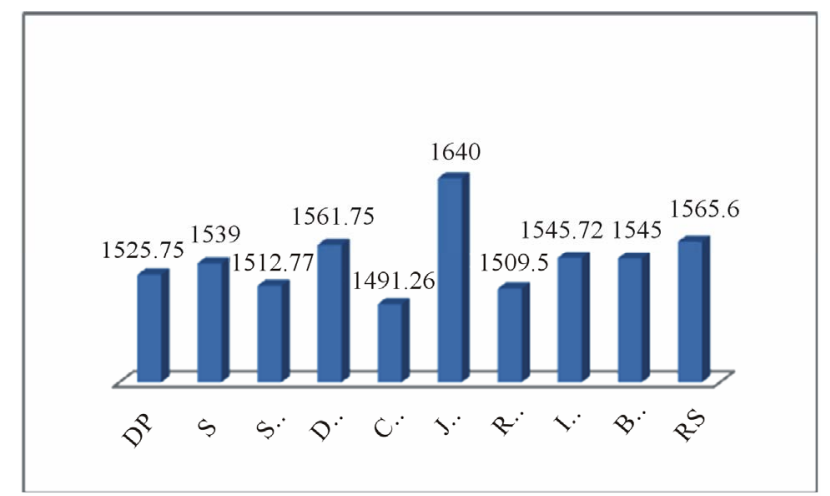

Figure 15.

Different locations of each pottery group (elevation in $\mathrm{m}$ ).

the water sources in the region could be assumed as an influencing factor to affect distribution of sites to shape a pattern by which dwellers found easy access to the water sources.

The following results are extracted regarding the samples of their period:

About 17/1 percent of sites have been assigned to the EC period covering a space of about $5235 \mathrm{~m}^{2} 23$ sites of which produced CHS pottery type and 3 sites provided JW type. 15 sits of this period were located in a distance less than $1000 \mathrm{~m}$ from rivers while some other more than $3000 \mathrm{~m}$. 23 sites are in average altitude of $1491 \mathrm{~m}$ and 3 sites are at $1640 \mathrm{~m}$. The interesting fact of this case is the form of $\mathrm{J}$ Ware. Such wares are mostly of open-mouth and of tray shape (Levine \& Young, 1986: pp. 19-20). As they stated these form of wares are not convenient for the migrating people to handle but suitable to utilize by the sedentary villagers.

On the other hand the environmental characteristics of site locations such as altitude may account to the point that the consumers of such wares were probably the people who lived in the permanent villages and used sedentary way of life for their living economy. The changes immediately occurred after the Late Neolithic in the open valleys of Western CZM, indicate an increase in the settlement areas of the region (Godin XI Period) so that the smaller villages were inhabited near the rivers, streams or springs (Smith \& Young, 1983; Abdi, 2003). The sites proliferation pattern and increasing the number of villages were clearly seen from Mahidasht plain during the Neolithic to Chalcolithic periods (Levine \& Mcdonald, 1977: p. 45).

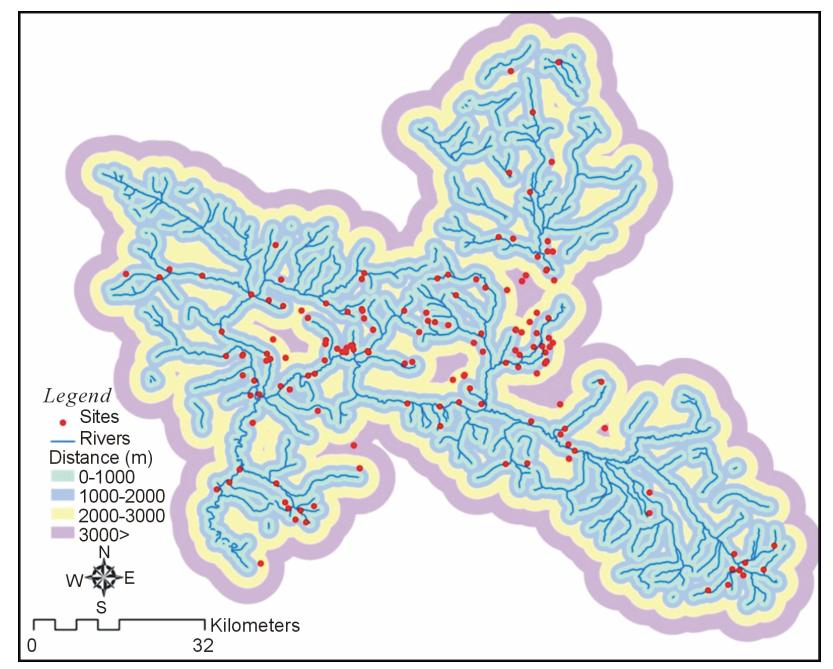

Figure 16.

Map showing the overall distances of Chalcolithic sites of the study.

Table 4.

Overall distances of sites from the rivers.

\begin{tabular}{ccc}
\hline $\begin{array}{c}\text { Number of } \\
\text { Sites }\end{array}$ & Percentage & $\begin{array}{c}\text { Distance from } \\
\text { Water Sources }(\mathrm{m})\end{array}$ \\
\hline 95 & $62.5 \%$ & $0-1000$ \\
39 & $25.65 \%$ & $1000-2000$ \\
13 & $8.5 \%$ & $2000-3000$ \\
5 & $3.28 \%$ & $<3000$ \\
Total & - & - \\
$\mathbf{1 5 2}$ & & \\
\hline
\end{tabular}

During the MC period various types of wares represent developments in pottery productions and also communications with the adjacent regions. The reports concerning presence of IDW types even in Azerbaijan region verifies this fact of interactions (Hamlin, 1975; Henrickson \& Vidali, 1987). Archaeological evidences from CZM, show two distinct economic strategies taking place in the MC period. The eastern CZM seems to have maintained village-based agricultural economy while western CZM shows more interactions with the lowland plains such as Hamrin, Diyala and Dehloran (Abdi, 2003: p. 436).

Evidently in this research, $33 / 5$ percent of the total sites discovered belong to the MC period which accounts for $10,597 \mathrm{~m}^{2}$ (Table 1). This represents a 16.4 percent growth in the settlements expansions and subsequent population increases over the previous period.

Number of sites representing various pottery types of the MC period are as following: 29 sites represent IDW type, 29 sites BOB, 9 sites SGP, 6 sites ROB, 4 sites DP and finally 4 sites represent DUP type. Among them 57 sites are located in nonpasture land and are placed in a distance less than $2000 \mathrm{~m}$ from rivers. The average altitude of their location is about 1500 $1550 \mathrm{~m}$ showing that these regions mostly meet the needs for sedentary communities. In addition, the overall characteristics of this period's pottery types seem to have been as storage wares appropriate for food supplies.

By the beginning of LC period the number of sites was increased to reach 110 sites (about two times more than the previous period (Table 1). This increase may due to the establish- 
ment of the new settlements or the increase of the average areas used, but not merely because of the population growth. By comparing the average areas used by LC and MC peoples, it is clear that there is no considerable differences existed (Table 1) thus; it may be used to conclude that the LC peoples were by no means sedentary peoples living in the permanent villages instead; they were living in a mobility condition. Gilbert (1983: p. 111) on the basis of his study in Kangavar region came to the same conclusion stressing that settlement density may have persisted relatively unchanged through several villages' strata until about 3500 BC. But it is noted that, in the Late-Middle to Late Chalcolithic, the number of permanent settlements dropped precipitously in favor of temporary campsites with increasing distance from the agricultural zone (Abdi, 2003: p. 425).

Though during the LC the variety of pottery types has been decreased but their production rates were highly increased as the greatest parts of the assemblages of this period contain just RS type. Approximately from this period 72/3 percent of total sites discovered. The average areas occupied by these sites is $11,287 \mathrm{~m}^{2}$; indicating a highly expansion rate than other periods. An increase of about 38.8 percent in settlements growth may imply to reflect the growing populations and their distribution throughout the region.

105 out of 110 sites possess RS and just 5 remaining sites represent $\mathrm{S}$ shaped type. The average altitude of this group is about $1549 \mathrm{~m}$ (Table 3). The distance of these sites from the rivers and their tributaries is less than $1000 \mathrm{~m}$. During this period pottery wares were produced for their functional purposes and production lines followed manufacturing all forms in bulk such as plain wares rather than paying attention to a specific one. This period witnessed a great demand for pottery wares. Nevertheless different forms of wares were still in use including opened and closed mouth vessels and shallow and deep vessels as well as trays of various types constituting some types of S shaped wares (Levine \& Young, 1986: p. 33).

In summary, based on the above reasoning, our study provided a category of settlement system for the region which includes agricultural village-based pastoralism and nomadism. This system would be well described by the environmental setting of sites such as altitudes as well as the many forms of pottery vessels produced in the Chalcolithic sites which they may well account to the point that the consumers of such vessels were probably the people who lived in the permanent villages and used sedentary way of life for their living economy. Such economy may be represented by an ideal capacity for agriculture and animal husbandry. And as a final point, although for the surveying strategy we applied "purposive" method by which any point of the surveying area were assessed. It led to noticeable ancient sites to be discovered and recorded. As a result, we have a considerable body of evidences about prehistoric occupations of the region, allowing us to draw a more precise picture of the settlement patterns during those times as well as changing and transforming patterns of them through a long-term process. So, a post surveying project conducted with the aim to understanding settlement patterns and processes of the valley during different periods of prehistory and their most affective and influential factors.

\section{Acknowledgements}

We are grateful to the Iranian National Science Foundation (INSF) for covering some parts of this research's financial need.
We would like to thank all the members of the survey team for their kindly cooperation. Grateful thanks to the Cultural Heritage Organization of Hamadan and Kermanshah provinces that provided our access to the site locations. We thank also Dr. Yaghob Mohamadifar from University of Bu Ali Sina of Hamedan for their kindly co-operations in providing the necessary data and maps.

\section{REFERENCES}

Abdi, K. (2003). The early development of pastoralism in the Central Zagros Mountains. Journal of World Prehistory, 17, 4. http://dx.doi.org/10.1023/B:JOWO.0000020195.39133.4c

Badler, R. V. (2002). The chronology of Uruk artifacts from Godin Tepe. In J. N. Postgate (Ed.), Artifacts of complexity tracking the Uruk in the Near East (pp. 79-109). Iraq Archaeological Reports. London: British School of Archaeology in Iraq.

Braidwood, L. S., Braidwood, R., Howe, B., Reed, C. A., \& Watson, P. J. (1983). Prehistoric archaeology along the Zagros flanks, Oriental Institute Publications 105. Chicago: University of Chicago Press.

Braidwood, R. J. (1958). Near Eastern prehistory. Science, 127, 14191430. http://dx.doi.org/10.1126/science.127.3312.1419

Braidwood, R. J. (1960a). Seeking the world's first farmers in Persian Kurdistan. Illustrated London News, 22nd October, 695-697.

Braidwood, R. J. (1960b). Preliminary investigations concerning the origins of food-production in Iranian Kurdistan. British Association for the Advancement of Science, 17, 214-218.

Contenau, G., \& Ghirshman, R. (1935). Fouilles de Tepe Giyan, pres de Nahavend, 1931-1932. Paris: Geuthner.

Gilbert, A. S. (1983). On the origins of specialized nomadic pastoralism in western Iran. World Archaeology, 15, 105-119.

Gilbert, A. S. (1975). Modern nomads and prehistoric pastoralists: The limits of analogy. The Journal of Ancient Near Eastern Society of Columbia University, 7, 53-71.

Goff, C. (1971). Luristan before the Iron Age. Iran, 4, 131-152. http://dx.doi.org/10.2307/4300443

Hamlin, C. (1975). Dalma Tepe. Iran, 8, 111-129. http://dx.doi.org/10.2307/4300529

Henrickson, E. F., \& Vidali, V. (1987). The Dalma tradition: Prehistoric interregional cultural integration in the highland of western Iran. Paleorient, 13, 37-46.

Henrickson, E. F. (1985a). An updated chronology of the Early and Middle Chalcolithic of the Central Zagros Highlands western Iran. Iran, 23, 63-108.

Henrickson, E. F. (1985b). The early development of pastoralism in the Central Zagros highlands Luristan. Iranica Antiqua, 20, 1-42. http://dx.doi.org/10.2143/IA.20.0.2014076

Henrickson, E. F. (1991). The Chalcolithic period in the Zagros Highlands. In E. Yarshater (Ed.), Encyclopedia Iranica, volume V. Costa Mesa, California: Mazda Publisher.

Henrickson, R. C. (1983). Giyan I and II reconsidered. Mesopotamia, 18-19, 195-220.

Henrickson, R. C., \& Mcdonald, M. A. (1983). Ceramics form and function. An ethnographic search and an archaeological application. American Anthropologist, 85, 640-643. http://dx.doi.org/10.1525/aa.1983.85.3.02a00070

Hole, F. (1987). The archaeology of western Iran: Settlement and society from prehistory to Islamic conquest. Washington DC: Smithsonian Institution Press.

Hole, F. (2011). Interactions between western Iran and Mesopotamia from the 9th-4th Millennia B. C. The Iranian Journal of Archaeological Studies, 1, 1-4.

Howel, R. (1979). Survey of the Malayer plain. Iran, 8, 156-157.

Levine, L. D. (1974). Archaeological investigations in the Mahidasht western Iran. Paleorient, 2, 487-490.

Levine, L. D., \& Mcdonald, M. (1977). The Neolithic and Chalcolithic period in Mahidasht. Iran, 15, 39-50.

Levine, L. D. (1975). The excavation at Seh Gabi. In F. Bagherzadeh (Ed.), Proceedings of the 3rd annual symposium on archaeological 


\section{B. BALMAKI ET AL.}

research in Iran (pp. 31-44). Tehran: Iranian Center for Archaeological Research.

Levine, L. D., \& Young Jr., T. C. (1986). A summary of the ceramic assemblages of the Central Western Zagros from the Middle Neolithic to the late third millennium BC. In Prehistoire de la mesopotamie: La mesopotamie prehistorique et $V$ exploration recente du Djebel Hamrin (pp. 15-53). Paris: Editions de la Centre National de la Recherche Scientifique (CNRS).

Meldgaard, J., Mortensen, P., \& Thrane, H. (1963). Excavation at Tepe Guran, Luristan. Acta Archaeologica, 34, 97-133.

Mortensen, P. (1972). Seasonal camps and early villages in the Zagros. In P. Ucko, R. Tringham, \& G. W. Dimbeleby (Eds.), Man, settlement and urbanism (pp. 293-297). London: Duckworth.

Mortensen, P. (1974). A survey of prehistoric settlements in Northern Luristan. Acta Archaeologia, 45, 1-47.

Niknami, K. A., \& Nikzad, M. (2012). New evidence of the Neolithic period in West Central Zagros: The Sarfirouzabad-Mahidasht region, Iran. Documenta Praehistorica, 34, 1-6.

Smith, P. E. L., \& Mortensen, P. (1980). Three new early Neolithic sites in western Iran. Current Anthropology, 21, 511-512. http://dx.doi.org/10.1086/202503

Smith, P., \& Young, T. C. (1983). The force of numbers; population pressure in central western Zagros, 12000-4500 BC. In T. C. Young, \& P. E. L. Smith (Eds.), The hilly flanks: Essays on the prehistory of southwestern Asia presented to Robert J. Braidwood, studies in Ancient Oriental Civilizations 36 (pp. 141-161). Chicago: The Oriental Institute of the University of Chicago.

Smith, P. E. L. (1976). Reflections on four seasons of excavations at Tapeh Ganj Dareh. In F. Bagherzadeh (Ed.), Proceedings of the 4th annual symposium on archaeological research in Iran (pp. 11-22). Tehran: Iranian Centre for Archaeological Research.

Smith, P. E. L. (1990). Architectural innovation and experimentation at Ganj Dareh, Iran. World Archaeology, 21, 323-335. http://dx.doi.org/10.1080/00438243.1990.9980111

Stocklin, G. (1968). Structural history and tectonics of Iran: A review. American Association of Petroleum Geologists Bulletin, 52, 12291258.

Young Jr., T. C., \& Smith, Ph. E. L. (1966). Research in the prehistory of Central Western Iran. Science, 153, 386-391. http://dx.doi.org/10.1126/science.153.3734.386

Young Jr., T. C. (1966). Survey in western Iran 1961. Journal of Near Eastern Studies, 25, 228-239. http://dx.doi.org/10.1086/371877

Young Jr., T. C. (1969). Excavation at Godin Tepe, first progress report. Toronto: Royal Ontario Museum, Vols. I \& II.

Young Jr., T. C. (1975a). An archaeological survey of the Kangavar valley. In F. Bagherzadeh (Ed.), Proceedings of the 3rd annual symposium on archaeological research in Iran (pp. 23-30). Tehran: Iranian Center for Archaeological Research.

Young Jr., T. C. (1963). Dalma painted ware. Expedition, 5, 38-39.

Young Jr., T. C. (1975b). Kangavar Valley survey. Iran, 13, 191-193.

Young Jr., T. C., \& Levine, L. D. (1974). Excavation of the Godin project: Second prrogress report, occasional papers no. 26, art and archaeology. Toronto: Royal Ontario Museum.

Zagarell, A. (1975). Archaeological survey in the north west Bakhtiari mountains. In F. Bagherzadeh (Ed.), Proceedings of the 2nd annual symposium on archaeological research in Iran (pp. 145-148). Tehran: Iranian Center for Archaeological Research. 